
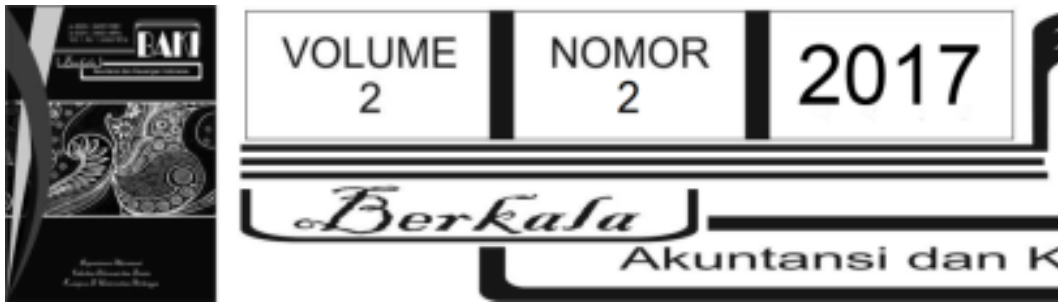

Loerkata

\title{
Pengaruh Knowledge Management Terhadap Kinerja Organisasi Dimediasi Inovasi di Organisasi Penelitian Pemerintah
}

\author{
Navik Puryantini ${ }^{1,2}$ \\ Rofikotul Arfati ${ }^{1}$ \\ Bambang Tjahjadi ${ }^{1}$ \\ ${ }^{1}$ FEB Universitas Airlangga \\ ²navik.puryantini@gmail.com
}

\begin{tabular}{|c|c|}
\hline INFO ARTIKEL & BSTRAK \\
\hline $\begin{array}{l}\text { Histori Artikel: } \\
\text { Tanggal Masuk } 2 \text { Agustus } 2017 \\
\text { Tanggal Diterima } 14 \text { Agustus } \\
2017 \\
\text { Tersedia Online } 30 \text { September } \\
2017 \\
\text { Kata Kunci: } \\
\text { inovasi; kinerja organisasi; } \\
\text { knowledge management }\end{array}$ & $\begin{array}{l}\text { Inovasi merupakan kekuatan penting dalam peningkatan kinerja } \\
\text { organisasi serta dapat meningkatkan pertumbuhan ekonomi dan } \\
\text { pembangunan (Agbim et al., 2013). Penelitian ini bertujuan untuk } \\
\text { mengetahui pengaruh inovasi sebagai variabel mediasi terhadap } \\
\text { hubungan knowledge management terhadap kinerja organisasi. } \\
\text { Penelitian ini menggunakan populasi pegawai organisasi } \\
\text { penelitian pemerintah. Sampel diambil secara klustering. Metode } \\
\text { analisa data yang digunakan dalam penelitian ini adalah Partial } \\
\text { Least Squares. Hasil penelitian menunjukkan bahwa ada } \\
\text { pengaruh langsung secara positif pada knowledge management } \\
\text { inovasi dan kinerja organisasi. Variabel inovasi tidak berhasil } \\
\text { berperan dalam hubungan knowledge management terhadap } \\
\text { kinerja organisasi. }\end{array}$ \\
\hline
\end{tabular}

\section{Pendahuluan}

Inovasi dianggap sebagai mekanisme penting untuk menjadi lebih kompetitif dan untuk bertahan hidup di dunia bisnis global (Salaman dan Storey 2002). Menurut Agbim et al., (2013) inovasi adalah kekuatan penting dalam peningkatan kinerja organisasi serta dapat meningkatkan pertumbuhan ekonomi dan pembangunan. Lebih dari itu, organisasi harus inovatif untuk bertahan hidup dan berkembang dalam lingkungan yang kompetitif dan cepat berubah. Untuk itu, hal penting dan yang harus dimiliki organisasi adalah keberhasilan menciptakan inovasi (Barney 1991). Sedangkan dalam Damanpour (1991) dijelaskan bahwa sebuah inovasi dapat berupa produk atau jasa yang baru, teknologi proses produksi yang baru, sistem struktur dan administrasi baru atau rencana baru bagi anggota organisasi. 
Untuk melakukan inovasi, organisasi dituntut mempunyai pengetahuan yang baik dan mendalam, sehingga dalam proses penciptaan pengetahuan berlangsung organisasi berusaha memperbaiki metode kerjanya. Proses inovasi banyak bergantung pada pengetahuan, terutama karena knowledge merepresentasikan suatu bidang (realm) jauh lebih dalam dari pada data, informasi dan logika konvensional; oleh karenanya, kekuatan pengetahuan terletak pada subjektivitasnya, yang mendasari value dan asumsi yang menjadi pondasi bagi proses pembelajaran (Nonaka dan Takeuchi 1995). Pengetahuan merupakan sumber daya utama dan memiliki peran penting untuk pencapaian keunggulan kompetitif berkelanjutan dan pencapaian kinerja. Sebagai salah satu aset kompetitif, pengetahuan harus dimiliki setiap individu untuk dapat mengembangkan keterampilan, sehingga melalui penguasaan pengetahuan dan keterampilan individu dapat mengelola karir mereka sendiri. Oleh karenanya pengetahuan harus dikelola melalui sistem knowledge management.

Organisasi Penelitian Pemerintah adalah lembaga riset yang menggunakan human capital sebagai sumber pengetahuan, inovasi, dan pembaharuan. Lembaga riset biasanya bergantung kepada komunikasi informal antara individu dan bersifat people-centric operations. Hal ini yang menyebabkan seringkali penyebaran pengetahuan terputus sehingga informasiinformasi penting tidak dapat tersampaikan dengan baik antara sesama individu pada lembaga tersebut. Untuk itu pengetahuan di dalam Organisasi Penelitian Pemerintah perlu dikelola dan didokumentasikan dengan menggunakan konsep knowledge management (knowledge management) yang merupakan suatu rangkaian kegiatan yang digunakan oleh organisasi atau institusi untuk mengidentifikasi, menciptakan, menjelaskan, dan mendistribusikan pengetahuan yang akan digunakan kembali, diketahui, dan dipelajari di dalam organisasi. Kegiatan ini biasanya terkait dengan objektif organisasi dan ditujukan untuk mencapai suatu hasil tertentu seperti pengetahuan bersama, peningkatan kinerja, keunggulan kompetitif, atau tingkat inovasi yang lebih tinggi.

Agar Organisasi Penelitian Pemerintah bisa mengembangkan teknologi secara mandiri maka harus ada knowledge management, keterampilan dan kemampuan SDM untuk menyerap IPTEK. Tujuan dari KMS memberi kemudahan kepada pegawai Organisasi Penelitian Pemerintah dalam memanfaatkan, mengekplorasi, dan berbagi pengetahuan, sehingga proses kreatifitas dan inovasi teknologi di lingkungan Organisasi Penelitian Pemerintah akan terdorong lebih luas dan setiap pegawai dengan cepat meningkatkan kompetensinya dengan harapan akan melahirkan inovasi-inovasi baru di Organisasi Penelitian Pemerintah. Perbedaan manajemen informasi dengan knowledge management adalah bahwa manajemen informasi berfokus pada pengelolaan pengetahuan eksplisit sedangkan knowledge management berfokus pada bagaimana menangkap tacit knowledge agar dapat diekplisitkan sehingga dapat berguna dan dimanfaatkan oleh orang lain, dan ini merupakan hal yang sulit sekaligus merupakan tantangan untuk Organisasi Penelitian Pemerintah. 
Dalam teori RBV dikatakan bahwa pengetahuan adalah aset utama selain dari yang intangible dalam suatu organisasi. Keberhasilan suatu organisasi tergantung pada knowledge management dalam menghadapi perubahan lingkungan. Menurut Barney (1991) bahwa Keunggulan kompetitif organisasi yang berkelanjutan berasal dari kekhasan dari sumber daya yang berharga, langka, tidak sempurna dan tidak imitable disubstitusikan.

Kinerja merupakan suatu proses yang digunakan oleh pimpinan untuk menentukan apakah seorang karyawan melakukan pekerjaan sesuai dengan tugas dan tanggung jawabnya atau tidak, sehingga langkah-langkah yang digunakan untuk mewakili kinerja dipilih berdasarkan keadaan organisasi yang sedang diamati. Kaplan dan Norton (1996) memperkenalkan balanced scorecard yang menekankan pada semua ukuran finansial dan nonfinansial menjadi bagian sistem informasi untuk para pekerja di semua tingkatan yang ada dalam organisasi/perusahaan.

Penelitian tentang hubungan konwledge management sudah banyak dilakukan. Bukti empiris dari penelitian Yousif Al-Hakim dan Hassan (2013) menyatakan bahwa strategi KM berpengaruh secara langsung terhadap kinerja organisasi dan juga berpengaruh tidak langsung melalui inovasi sebagai variabel mediasi. Penelitian ini dilakukan pada sektor telekomunikasi ponsel di Iraq. Hasil penelitian Yousif Al-Hakim dan Hassan (2013) ini didukung oleh penelitian Carolina dan Angel (2011) yang menganalisis hubungan Strategic knowledge management $(\mathrm{KM})$, strategi inovasi perusahaan dan kinerja organisasi pada 310 organisasi Spanyol. Hasil penelitian menunjukan bahwa kedua strategi KM (kodifikasi dan personalisasi) berpengaruh terhadap inovasi dan kinerja organisasi secara langsung maupun tidak langsung. Penelitian yang sama juga dilakukan oleh López-Nicolás dan Meroño-Cerdán (2011) yang hasilnya mendukung penelitian Yousif Al-Hakim dan Hassan (2013) dan Carolina dan Angel (2011).

Penelitian Yeşil, Koska, dan Büyükbeşe (2013) memfakuskan pada berbagi pengetahuan (knowledge sharing) terhadap kemampuan inovasi dan kinerja inovasi. Hasil dari penelitian ini menunjukan bahwa sharing knowledge tidak bebengaruh terhadap kemampuan inovasi dan kinerja inovasi. Penelitain Yeşil et al., (2013) didukung penelitiannya Noviyanti dan Mulyanto (2015) yang menunjukkan bahwa knowledge management berpengaruh terhadap inovasi, namun inovasi tidak mempunyai pengaruh terhadap kinerja

Mengacu pada uraian di atas, terdapat pandangan literatur dan gap pada hasil penelitian terdahulu, maka motivasi penelitian ini adalah menguji pengaruh knowledge management terhadap inovasi dan kenerja organisasi. Orisinalitas dari penelitian ini adalah pengaruh variabel knowledge management terhadap inovasi dan kinerja organisasi.

Berdasarkan hal tersebut diatas maka terdapat beberapa permasalahan yang perlu diteliti antara lain: (1). bagaimana pengaruh knowledge management terhadap inovasi, (2). Bagaimana pengaruh knowledge management terhadap kinerja organisasi, (3). bagaimana pengaruh knowledge management terhadap kinerja organisasi dimediasi inovasi. 
Penelitian ini diharapakan dapat memberikan bukti empiris mengenai pengaruh knowledge management terhadap kinerja organisasi yang dimediasi inovasi. Selain itu penelitian ini diharapkan memberikan petunjuk bagi Organisasi Penelitian Pemerintah dalam menggambarkan sejauh mana knowledge management terhadap inovasi dan kinerja organisasi, yang dapat menjadi masukan bagi Organisasi Penelitian Pemerintah dalam rangka mengambil langkah-langkah untuk meningkatkan kinerja organisasi.

\section{Tinjauan Pustaka}

\subsection{Resource-Based View (Pandangan Berbasis Sumber Daya)}

Pada awal dekade tahun 1990-an, ada suatu perubahan terhadap perspektif yang meletakkan organisasi ke pandangan lebih dekat terhadap faktor sumber daya organisasi sebagai keuntungan kompetitif Resource-Based View (RBV). RBV bertujuan pada pentingnya menyajikan sumber daya organisasi yang spesifik dalam meraih keuntungan kompetitif yang mendukung (Nothnagel 2008). Substansi utama resource-based view adalah sumberdaya yang mampu menghasilkan keunggulan bersaing berkelanjutan yaitu sumberdaya yang bernilai, langka atau unik, sulit untuk ditiru, dan tidak ada substitusinya (J. Barney 1991). Berawal dari literatur manajemen strategi, Knowledge-Based View (KBV) dibangun berdasarkan perspektif ini dan memperluas pandangan berbasis sumber daya organisasi (RBV).

\subsection{Knowledge Management}

Pengetahuan semakin diakui sebagai asset yang penting dari organisasi. Paradigma paling terbaru adalah pengetahuan merupakan kekuatan. Dalam perekonomian modern, organisasi yang memanfaatkan pengetahuan adalah organisasi yang memiliki keunggulan kompetitif. Keunggulan kompetitif tersebut diwujudkan melalui pemanfaatan penuh informasi dan data yang digabungkan dengan memanfaatkan keterampilan, ide, komitmen dan motivasi dari karyawan. Paradigma baru dewasa ini adalah bahwa pengetahuan dalam organisasi harus dibagi dalam rangka untuk mendukung pertumbuhan dan perkembangan organisasi (Uriarte 2008). Tipe pengetahuan ada dua yaitu (1) Pengetahuan Implicit (tacit) yaitu merupakan pengetahuan yang masih berada dalam pikiran individu yang memiliki pengetahuan tersebut dan bersifat pribadi. Sedangkan Dengan demikian, adalah penting untuk sebuah organisasi untuk menemukan, menyebarkan dan memanfaatkan pengetahuan impisit dari masing-masing karyawan dalam rangka mengoptimalkan penggunaan modal intelektualnya sendiri. (Nonaka 1995). (2) Pengetahuan eksplisit (explicit) adalah pengetahuan yang secara eksplisit tersedia 
dalam organisasi. Pada umumnya pengetahuan eksplisit bersifat terstruktur dan tercermin dalam berbagai rujukan peraturan dan standar kerja dalam organisasi.

Perbedaan antara pengetahuan tacit dan pengetahuan explicit menyarankan 4 pola dasar untuk menciptakan pengetahuan dalam organisasi (Nonaka 1995). (1) Sosialisasi (dari tacit ke tacit), (2) Eksternalisasi (dari tacit ke explicit) , (3) Kombinasi dari eksplisit ke eksplisit dan (4) Internalisasi dari eksplisit ke tacit. Banyak definisi manajemen pengetahuan dari berbagai peneliti. Masing-masing memberikan penafsiran berdasarkan latar belakang profesi dan tujuan penelitan. Penelitian ini mengacu pada Honeycutt (2000) yang mengemukakan proses utama dalam knowledge management meliputi penciptaan pengetahuan (creation), penggunaan pengetahuan (utilization) dan berbagi pengetahuan (sharing). Knowledge creation merupakan aktifitas untuk menciptakan pengetahuan. Pengetahuan di dapat dari informasi yang berupa pengalaman dan keahlian individu. Knowledge utilization adalah kegiatan yang berhubungan dengan aplikasi pengetahuan berupa perangkat teknis antara lain mesin dan peralatan yang digunakan untuk peningkatan nilai tambah atau produktivitas. Knowledge sharing menyangkut aktifitas pemindahan pengetahuan dari satu pihak ke pihak lain. Berbagi pengetahuan berarti setiap individu menyadari pentingnya pengetahuan bagi perusahaan dan membagi ilmu yang didapat dengan individu yang lain.

\subsection{Kinerja Organisasi}

Kinerja merupakan suatu proses yang digunakan oleh pimpinan untuk menentukan apakah seorang karyawan melakukan pekerjaan sesuai dengan tugas dan tanggung jawabnya atau tidak, sehingga langkah-langkah yang digunakan untuk mewakili kinerja dipilih berdasarkan keadaan organisasi yang sedang diamati. Penelitian ini mengacu pada konsep Kaplan dan Norton (1996) yang memperkenalkan balanced scorecard yang menekankan pada semua ukuran finansial dan nonfinansial menjadi bagian sistem informasi untuk para pekerja di semua tingkatan yang ada dalam organisasi/perusahaan. Balanced scorecard tersusun ke dalam empat perspektif yang berimbang, yaitu: 1) persepektif finansial, 2) persepektif pelanggan, 3) perspektif proses bisnis internal, dan 4) persepektif proses pembelajaran dan pertumbuhan.

\subsection{Penelitian Terdahulu dan Pengembangan Hipotesis}

Studi ini dilakukan diawali dengan kerangka proses berpikir yaitu melakukan telaah teoritis tentang Teori RBV. Teori tersebut dipelajari karena memiliki relevansi dengan permasalahan yang diajukan dalam studi ini.Hal ini dilakukan karena teori mempunyai sifat universal yang artinya berlaku dimana saja, kapan saja dan umum, tetapi bisa diterapkan pada 
kasus-kasus spesifik yang mengandung kesimpulan bersifat umum menuju kesimpulan bersifat khusus. Alur pikir ini menunjukkan logika deduktif.

Studi empiris dilakukan dengan cara mempelajari penelitian terdahulu yang terkait dengan permasalahan yang diangkat dalam penelitian ini. Pada saat melakukan studi empiris terjadi proses generalisasi dari hal-hal yang bersifat khusus ke hal yang bersifat umum. Alur pikir ini menunjukkan logika induktif. Berdasarkan paparan diatas maka hipotesis dalam penelitian ini adalah

\subsubsection{Knowledge Management dan Inovasi}

Proses inovasi banyak bergantung pada pengetahuan, terutama karena knowledge merepresentasikan suatu bidang (realm) jauh lebih dalam dari pada data, informasi dan logika konvensional; oleh karenanya, kekuatan knowledge terletak pada subjektivitasnya, yang mendasari value dan asumsi yang menjadi pondasi bagi proses pembelajaran (Nonaka dan Takeuchi 1995). Inovasi berkaitan dengan knowledge yang dapat digunakan untuk menciptakan produk atau proses dan layanan baru guna meningkatkan competitive advantage dan memenuhi kebutuhan pelanggan yang selalu berubah. Untuk itu dirumuskan hipotesa

\section{H1 : Knowledge management mempunyai pengaruh langsung terhadap Inovasi}

\subsubsection{Knowledge Management dan Kinerja Organisasi}

Pandangan sumber daya berbasis pengetahuan merupakan pendekatan untuk memahami hubungan antara kemampuan organisasi dan kinerja oganisasi. Teori sumber daya berbasis pengetahuan menyatakan bahwa pengetahuan adalah yang paling strategis signifikan sebagai sumber daya perusahaan. Sumber daya berbasis pengetahuan biasanya sulit untuk ditiru oleh organisasi lain dan sebagai sumber keunggulan kompetitif. Knowledge management telah muncul sebagai sumber dari keunggulan kompetitif yang berkelanjutan (J. Barney, 1991). Knowledge management merupakan salah satu alat manajemen yang dapat digunakan untuk mendukung pencapaian tujuan organisasi dan menunjukkan keunggulan bersaing sehingga mampu menciptakan kinerja organisasi yang baik (Megantoro et al., 2014). Bukti empiris Nielsen, Rasmussen, Hsiao, Chen, dan Chang (2011) mengatakan bahwa Knowledge management capacity, knowledge acquisition dan diseminasi berhubungan positif dengan kinerja organisasi. Untuk itu dirumuskan hipotesa

\section{H2 : Knowledge management mempunyai pengaruh langsung terhadap Kinerja Organisasi}




\subsubsection{Inovasi dan Kinerja Organisasi}

Penelitian Al-Ansari et al. (2013) menujukan bahwa ada hubungan positif yang signifikan antara inovasi dan kinerja bisnis. Selanjutnya Zehir et al. (2011) memberikan dukungan pada penelitian Al Ansari et al. (2013) dan penelitian ini, Zehir et al. (2011) menggunakan sampel 159 perusahaan milik keluarga dari database Istanbul Chamber of Commerce di wilayah Marmara, Turkey menunjukan hasil bahwa pengaruh positif dari inovasi atau orientasi hubungan pada kinerja organisasi. Untuk itu dirumuskan hipotesa

\section{H3 : Inovasi mempunyai penagruh langsung terhadap Kinerja Organisasi}

\subsubsection{Knowledge Management, Inovasi dan Kinerja Organisasi}

Hubungan antara KM dan inovasi, serta hubungan antara inovasi kinerja organisasi dikembangkan berdasarkan teori RBV. Dalam teori RBV dikatakan bahwa pengetahuan adalah aset utama selain dari yang tengible dalam suatu organisasi. Keberhasilan suatu organisasi tergantung pada menajemen pengetahuan dalam menghadapi perubahan lingkungan. Kemampuan beradaptasi dengan perubahan lingkungan akan meningkatkan inovasi dan kinerja organisasi. Bukti empiris Yousif Al-Hakim dan Hassan (2013) menyatakan bahwa strategi KM berpengaruh secara langsung terhadap kinerja organisasi dan juga berpengaruh tidak langsung melalui inovasi sebagai variabel mediasi. Penelitian ini dilakukan pada sektor telekomunikasi ponsel di Iraq. Carolina dan Angel (2011) menganalisis hubungan Strategic knowledge management $(\mathrm{KM})$, strategi inovasi perusahaan dan kinerja organisasi pada 310 organisasi Spanyol menggunakan persamaan struktural modeling Hasil penelitian menunjukan bahwa kedua strategi KM (kodifikasi dan personalisasi) berpengaruh terhadap inovasi dan kinerja organisasi secara langsung maupun tidak langsung (melalui peningkatan pada kemampuan inovasi). Hubungan antara knowledge management, inovasi dan kinerja juga diteliti oleh LópezNicolás dan Meroño-Cerdán (2011) menyatakan bahwa KM berpengaruh terhadap Kinerja Organisasi baik secara langsung dan tidak langsung melalui inovasi.

Penelitian Yeşil et al. (2013) memfokuskan pada berbagi pengetahuan (knowledge sharing) terhadap kemampuan inovasi dan kinerja inovasi. Hasil dari penelitian ini menunjukan bahwa sharing knowledge tidak bebengaruh terhadap kemampuan inovasi dan kinerja inovasi. Penelitain ini dilakukan pada perusahaan yang ada di Turki. Noviyanti dan Mulyanto (2015) yang berjudul Pengaruh Knowledge management Terhadap Inovasi, Implementasi Strategi dan Kinerja Organisasi (Studi Pada RS Lavalette Malang) menunjukkan bahwa bahwa knowledge management berpengaruh terhadap inovasi, namun inovasi tidak mempunyai pengaruh terhadap kinerja. Untuk itu dirumuskan hipotesa

\section{H4 : Knowledge management mempunyai pengaruh terhadap Kinerja Organisasi melalui}




\section{Inovasi}

\subsection{Kerangka Konseptual}

Berdasarkan paparan yang telah dibahas sebelumnya, maka model yang diusulkan dalam penelitian ini adalah sebagai berikut:

\section{Gambar 1 Kerangka Koseptual}

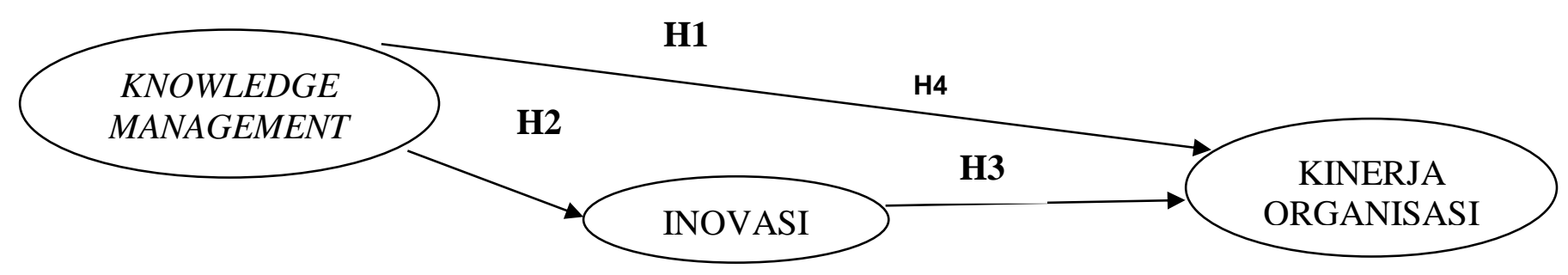

\section{Metodologi Penelitian}

\subsection{Jenis Penelitian}

Jenis penelitian yang akan dilakukan adalah penelitian kuantitatif dan kualitatif eksploratori dengan tujuan untuk mengetahui pengaruh Knowledge management terhadap inovasi serta kinerja organisasi.

\subsection{Definisi Operasional dan Pengukuran Variabel}

\subsubsection{Knowledge Management (X1)}

Knowledge management yang digunakan dalam penelitian ini mengunakan konsep dari Honeycutt (2001) yang meliputi penciptaan pengetahuan,penggunaan pengetahuan dan berbagi pengetahuan dengan indikatornya sebagai berikut:

1. Knowledge management: Proses manajemen yang berorientasi untuk menciptakan pengetahuan

2. Knowledge utilization: kegiatan yang berhubungan dengan aplikasi pengetahuan berupa perangkat teknis antara lain mesin dan peralatan yang digunakan untuk peningkatan nilai tambah atau produktivitas

3. Knowledge sharing: menyangkut aktifitas pemindahan pengetahuan dari satu pihak ke pihak lain 


\subsubsection{Inovasi $(Z)$}

Sesuai yang disampaikan oleh Damanpour dan Schneider (2009) inovasi merupakan sebuah pengenalan peralatan, sistem, hukum, produk atau jasa, teknologi proses produksi yang baru, sebuah struktur atau sistem administrasi yang baru, atau program perencanaan baru yang untuk diadopsi sebuah organisasi. Dalam penelitian ini hanya menggunakan inovasi proses dan inovasi produk.

\subsubsection{Kinerja Organisasi (Y)}

Dalam penelitian ini kinerja organisasi diukur dari perspektif berimbang antara internaleksternal mengacu pada konsep balance scorecard (Kaplan dan Norton 1996). Kinerja organisasi diukur dari empat perspektif atau indikator, yaitu: Perspektif non-finansial, Perspektif pelanggan, Perspektif proses operasional, dan Perspektif pembelajaran dan pertumbuhan.

\subsection{Jenis dan Sumber Data}

Sumber data penelitian diperoleh dari data primer. Data primer didapatkan melalui alat bantu berupa kuesioner dan wawancara dengan beberapa informan.

\subsection{Populasi dan Sampel}

Populasi pada penelitian ini adalah seluruh pegawai salah satu Organisasi Penelitian Pemerintah, Penelitian ini menggunakan metode analisa Partial Least Square yang berbasis komponen maka jumlah sampel yang digunakan tidak perlu besar. Sampel yang digunakan dapat berkisar 30-100.

\subsection{Metode Pengumpulan Data}

Pengumpulan data dengan menggunakan metode kuesioner. Dengan metode ini, maka akan diajukan sejumlah pertanyaan dalam bentuk daftar pertanyaan kepada sampel yang menjadi responden dalam penelitian dalam rangka pengumpulan data. Responden diminta untuk menjawab pertanyaan atau memberikan tanggapan pada alternatif jawaban yang telah disediakan. Daftar pertanyaan pada kuesioner penelitian menggunakan pengukuran Likert Scale (Skala Likert), mengambil skala dengan rentangan nilai 1 s.d 5 yakni skala 1 menunjukkan sangat tidak setuju, 2 menunjukkan tidak setuju, 3 menunjukkan ragu-ragu, 4 menunjukkan setuju, dan 5 menunjukkan sangat setuju. 
Pengumpulan dengan menggunakan wawancara langsung sebagai alat pembuktian terhadap keterangan yang diperoleh sebelumnya. Teknik wawancara yang digunakan dalam penelitian ini adalah wawancara mendalam. Wawancara mendalam adalah proses memperoleh keterangan untuk tujuan penelitian dengan cara tanya jawab sambil bertatap

\subsection{Teknik Analisis Data}

Metode analisa data yang digunakan dalam penelitian ini adalah Partial Least Square yang merupakan metode analisis yang powerful karena tidak mengasumsikan data harus menggunakan skala tertentu dan dapat menggunakan sampel yang kecil. Partial Least Square juga dapat digunakan untuk konfirmasi teori. Jika dibandingkan dengan covariance based SEM, maka component bases PLS mampu menghindarkan dua masalah besar yang dihadapi covariance based SEM (CBSEM) yaitu inadmissible solution dan faktorindeterminacy (Fornell dan Bookstein 1982). Hipotesis dalam penelitian ini akan diuji dengan menggunakan Partial List Square (PLS), yaitu berdasarkan nilai $p$-value dan kemudian juga akan dianalisis koefisien regresi dan koefisien determinasi.

\subsection{Model Spesifikasi Dengan Partial Least Square}

Model analisis jalur semua variabel laten dalam PLS terdiri dari tiga set hubungan: (1) inner model yang menspesifikasi hubungan antar variabel laten (structural model); (2) outer model yang menspesifikasi hubungan antara variabel laten dengan indikator atau variabel manifestnya (measurement model); (3) weight relation dalam mana nilai kasus dari variabel laten dapat diestimasi (Ghozali 2008).

\subsection{Evaluasi Model}

Model evaluasi Partial Least Square berdasarkan pada pengukuran prediksi yang mempunyai sifat non parametrik. Adapun model dalam PLS yang harus dievaluasi adalah :

a. Model pengukuran atau outer model dengan indikator refleksif dievaluasi dengan convergent dan discriminant validity dari indikatornya serta composite reliability untuk block indicator. Sedangkan outer model dengan indikator formatif dievaluasi berdasarkan substantive contentnya yaitu membandingkan besarnya relative weight dan melihat signifikansi dari ukuran weight tersebut (Chin 1998).

b. Model struktural atau inner model dievaluasi dengan meihat persentase variance yang dijelaskan dengan melihat nilai R2 untuk konstruk laten dependen dengan menggunakan Stone-Geisser $Q$ Squares Test (Stone 1974; Geisser 1975) dan juga melihat besarnya 
koefisien jalur strukturalnya. Stabilitas dari estimasi ini dievaluasi dengan menggunakan uji tstatistik yang didapat dari prosedur Bootstraping.

\section{Analisis Dan Pembahasan}

\subsection{Pengujian Pengaruh Langsung}

\subsubsection{Pengaruh Langsung Knowledge Management Terhadap Inovasi}

Pengaruh langsung variabel Knowledge management Terhadap Inovasi. nilai loading dari indikator Knowledge management dan Inovasi $\geq 0,5$ dengan nilai $p$-value kurang dari $5 \%$ (signifikan), hal ini berarti pengukuran konstruk Knowledge management dan Inovasi telah memenuhi syarat validitas konvergen. Nilai Composite Reliability Coefficients dan Cronbach's Alpha Coefficients dari variabel Knowledge management dan Inovasi menunjukkan nilainya lebih dari 0,70 yang berarti variabel Knowledge management dan Inovasi adalah reliable.. Nilai Full colinearity VIF pada variabel Knowledge management dan Inovasi kurang dari 3,3 maka dapat dikatakan bahwa model bebas dari masalah kolinearitas vertikal, lateral dan common method bias. Nilai Average Path Coefficient(APC) yang dihasilkan sebesar 0.570 dan signifikan kurang dari 1\%.Nilai Average R-Square (ARS) sebesar 0,325 dan signifikan pada $5 \%$ dan Nilai Average Variance Inflation Factor(AVIF) sama dengan 1 kurang dari 5. Dengan demikian, dapat disimpulkan bahwa goodness of fit model telah terpenuhi.

Koefisien jalur yang dihasilkan adalah positif yaitu sebesar 0,570 dengan $p$-value kurang dari $1 \%$. Hal ini berarti Knowledge management berpengaruh positif signifikan terhadap Inovasi yaitu semakin baik Knowledge management maka Inovasi semakin baik. Hubungan Knowledge management dengan kinerja Organisasi dapat dilihat pada gambar berikut ini:

\section{Gambar 2. Pengaruh Langsung Knowledge Management Terhadap Inovasi}

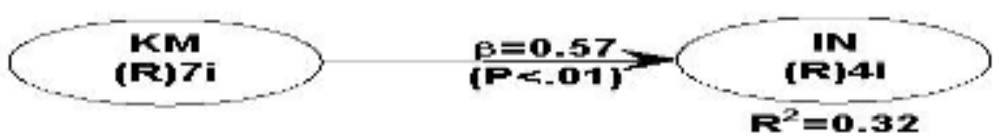

Sedangkan nilai EffectSize yang dihasilkan sebesar 0,325 , nilai ini melebihi 0,15 menunjukkan bahwa Knowledge management memiliki pengaruh yang medium terhadap Inovasi. Besarnya pengaruh Knowledge management terhadap Inovasi dapat dilihat dari nilai $R$ Squared Coefficients yaitu sebesar 0,325 yang berarti besarnya pengaruh Knowledge management terhadap Inovasi adalah sebesar 32,5\%. 


\subsubsection{Pengaruh Langsung Knowledge Management Terhadap Kinerja Organisasi}

Nilai loading dari indikator Knowledge management dan Kinerja organisasi $\geq 0,5$ dengan nilai $p$-value kurang dari $5 \%$ (signifikan), hal ini berarti pengukuran konstruk Knowledge management dan Kinerja organisasi telah memenuhi syarat validitas konvergen. Nilai Composite Reliability Coefficients dan Cronbach's Alpha Coefficients dari variabel Knowledge management dan Kinerja organisasi menunjukkan nilainya lebih dari 0,70 yang berarti variabel Knowledge management dan Kinerja organisasi adalah reliable. Full colinearity VIF pada variabel Knowledge management dan Kinerja organisasi kurang dari 3,3 maka dapat dikatakan bahwa model bebas dari masalah kolinearitas vertikal, lateral dan common method bias. Nilai Average Path Coefficient(APC) yang dihasilkan sebesar 0.476 dan signifikan kurang dari 5\%.Nilai Average R-Square (ARS) sebesar 0,226 dan Nilai Average Variance Inflation Factor(AVIF) sama dengan 1 kurang dari 5. Dengan demikian, dapat disimpulkan bahwa goodness of fit model telah terpenuhi

Koefisien jalur yang dihasilkan adalah positif yaitu sebesar 0,476 dengan $p$-value kurang dari 5\%. Hal ini berarti Knowledge management berpengaruh positif signifikan terhadap Kinerja organisasi yaitu semakin baik Knowledge management maka Kinerja organisasi semakin baik. Hubungan Knowledge management dengan kinerja Organisasi dapat dilihat pada gambar berikut ini:

\section{Gambar 3. Pengaruh Langsung Knowledge Management Terhadap Kinerja Organisasi}

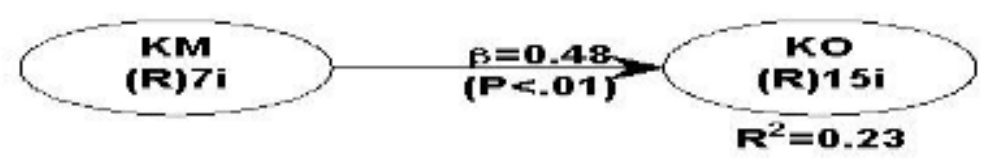

Sedangkan nilai EffectSize yang dihasilkan sebesar 0,226, nilai ini melebihi 0,15 menunjukkan bahwa Knowledge management memiliki pengaruh yang medium terhadap Kinerja organisasi. Besarnya pengaruh Knowledge management terhadap Kinerja organisasi dapat dilihat dari nilai $R$-Squared Coefficients yaitu sebesar 0,23 yang berarti besarnya pengaruh Knowledge management terhadap Kinerja organisasi adalah sebesar $23 \%$.

\subsubsection{Pengaruh Langsung Inovasi Terhadap Kinerja Organisasi}

Nilai loading dari indikator Inovasi dan Kinerja organisasi $\geq 0,5$ dengan nilai $p$-value kurang dari 1\% (signifikan), hal ini berarti pengukuran konstruk Inovasi dan Kinerja organisasi telah memenuhi syarat validitas konvergen. Nilai Composite Reliability Coefficients dan Cronbach's Alpha Coefficients dari variabel Inovasi dan Kinerja organisasi menunjukkan 
nilainya lebih dari 0,70 yang berarti variabel Inovasi dan Kinerja organisasi adalah reliable. Nilai Full colinearity VIF pada variabel Inovasi dan Kinerja organisasi kurang dari 3,3 maka dapat dikatakan bahwa model bebas dari masalah kolinearitas vertikal, lateral dan common method bias. Nilai Average Path Coefficient (APC) dan Average R-Square (ARS). Nilai Average Path Coefficient(APC) yang dihasilkan sebesar 0,330 dan signifikan kurang dari 1\%.Nilai Average $R$ Square (ARS) sebesar 0,109 dan Nilai Average Variance Inflation Factor(AVIF) sama dengan 1 kurang dari 5. Dengan demikian, dapat disimpulkan bahwa goodness of fit model telah terpenuhi.

Koefisien jalur yang dihasilkan adalah positif yaitu sebesar 0,33 dengan $p$-value $>10 \%$ (tidak signifikan). Hal ini berarti Inovasi tidak berpengaruh terhadap Kinerja organisasi. Hubungan Inovasi dengan kinerja Organisasi dapat dilihat pada gambar berikut ini:

\section{Gambar 4. Pengaruh Langsung Inovasi Terhadap Kinerja organisasi}

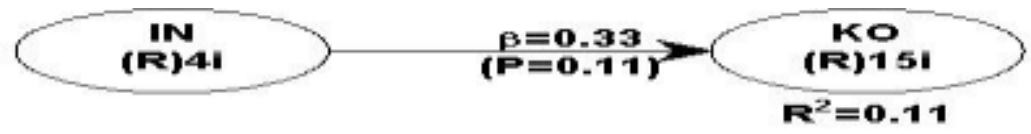

\subsection{Uji Pengaruh Tidak Langsung}

Uji pengaruh tidak langsung yang dimaksudkan adalah uji hubungan knowledge management dengan Kinerja Organisasi melalui variabel mediasi inovasi, dan menguji hubungan budaya organisasi dengan Kinerja organisasi melalui variabel inovasi

\subsubsection{Knowledge Management Mempunyai Pengaruh Terhadap Kinerja Organisasi Melalui Inovasi, Uji Validitas, Relaibilitas, Kolineritas, Dan Kecocokan Model Data}

Uji validitas, reliabilitas, kolinearitas dan kecocokan model data. Nilai loading dari indikator knowledge management, inovasi dan kinerja organisasi lebih dari 0,50 dengan nilai $p$ value kurang dari $5 \%$ (signifikan), hal ini berarti pengukuran konstruk knowledge management, inovasi dan kinerja organisasi telah memenuhi syarat validitas konvergen. Validitas konvergen juga bisa dilihat dari nilai AVE.Nilai AVE dari variabel knowledge management, inovasi dan kinerja organisasi lebih dari 0,50 yang berarti pengukuran konstruk knowledge management, inovasi dan kinerja organisasi telah memenuhi syarat validitas konvergen.

Uji reliabilitas dapat dilihat dari nilai Composite Reliability Coefficients dan Cronbach's Alpha Coefficients dari variabel knowledge management, inovasi dan kinerja organisasi. Nilai Composite Reliability Coefficients dan Cronbach's Alpha Coefficients dari variabel knowledge 
management, inovasi dan kinerja organisasi lebih dari 0,70 yang berarti variabel knowledge management, inovasi dan kinerja organisasi adalah reliabel. Untuk uji kolinearitas pada data penelitian ini sudah bebas dari masalah kolinearitas karena nilai full collinearity pada variabel knowledge management, inovasi dan kinerja organisasi kurang dari 3,3.

Untuk uji Kecocokan Model dapat dilihat pada nilai Average Path Coefficient (APC) dan Nilai Average R-Square (ARS).Nilai Average Path Coefficient (APC) yang dihasilkan sebesar 0,408 dan signifikan kurang dari 1\%.Nilai Average $R$-Square (ARS) yang dihasilkan sebesar 0,193. Nilai Average Variance Inflation Factor (AVIF) sebesar 1,056 kurang dari 5.Dengan demikian, dapat disimpulkan bahwa goodness of fit model telah terpenuhi.

\subsubsection{Hasil Estimasi Koefisien Jalur, Effect Size dan R-Squared}

Hasil Estimasi Koefisien Jalur, Effect Size dan $R$-Squared. Koefisien jalur yang dihasilkan dari pengujian pengaruh tidak langsung variabel Knowledge management terhadap Kinerja organisasi melalui inovasi adalah positif. Knowledge management berpengaruh positif signifikan $1 \%$ terhadap inovasi, pengaruh Knowledge management terhadap kinerja organisasi berpengaruh positif dan signifikan $1 \%$, pengaruh inovasi terhadap kinerja organisasi berpengaruh negatif dan tidak signifikan.

Nilai Effect Size antara variabel knowledge management dengan inovasi sebesar 0,325, nilai ini mendekati 0,35 menunjukkan bahwa knowledge management memiliki pengaruh yang cukup besar terhadap Inofasi. Nilai Effect Size antara variabel knowledge management dengan Kinerja organisasi sebesar 0.138 , menunjukkan bahwa knowledge management memiliki pengaruh medium terhadap kinerja organisasi. Nilai Effect Size antara variabel Inovasi dengan kinerja organinisasi sebesar 0,170, menunjukkan bahwa inovasi memiliki pengaruh yang medium terhadap kinerja organisasi. Variasi kinerja organisasi dapat dijelaskan oleh variasi knowledge management dan inovasi sebesar $6 \%$, sedangkan variasi inovasi dapat dijelaskan oleh variasi knowledge management sebesar $32 \%$.

Sebelumnya, pada model direct effect pada (4.1.c) menunjukkan bahwa knowledge management berpengaruh terhadap kinerja organisasi sebesar 0,48 dan secara statistik signifikan pada level $1 \%$. Hal ini berarti knowledge management berpengaruh signifikan secara statistik terhadap kinerja organisasi yaitu semakin baik knowledge management maka kinerja organisasi semakin baik.Nilai koefisien determinasi (R2) menunjukkan bahwa variansi Kinerja organisasi dapat dijelaskan oleh variansi knowledge management sebesar $32 \%$.

Pada model indirect effect yang ditunjukkan pada Gambar menunjukkan bahwa pengaruh langsung Knowledge management terhadap kinerja organisasi signifikan pada level $1 \%$ dengan nilai koefisien jalur turun menjadi 0.42 . Karena salah satu hubungan variabel pemediasi tidak signifikan maka dikatakan bukan sebagai variabel mediasi sehingga tidak 
dilakukan pengujian pengaruh mediasi variabel inovasi terhadap hubungan Knowledge management dengan Kinerja Organisasi. Hipotesis ke enam dalam penelitian ini yang menyatakan Knowledge management mempunyai pengaruh terhadap Kinerja Organisasi melalui Inovasi tidak terbukti.

\section{Gambar 5. Inovasi Memediasi Hubungan Knowledge management terhadap Kinerja Organisasi}

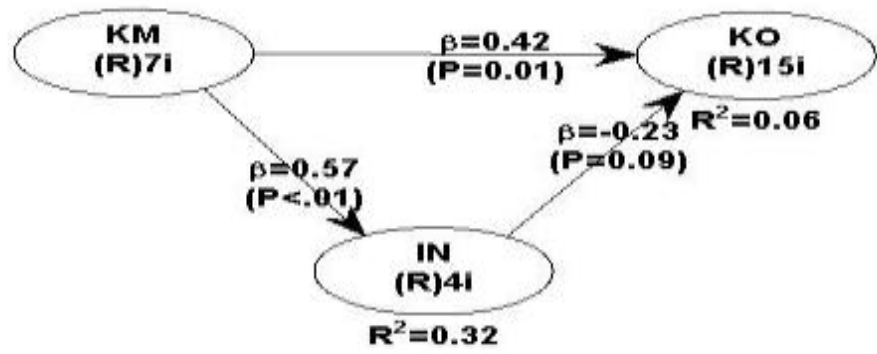

\subsection{Pembahasan}

Hasil penelitian ini menunjukkan dukungan empiris adanya hubungan positif dan signifikan antara variabel knowledge management terhadap kinerja organisasi, hal ini sesuai dengan penelitiannya Barney (1991) yang menyatakan bahwa Knowledge management telah muncul sebagai sumber dari keunggulan kompetitif yang berkelanjutan. Knowledge management merupakan salah satu alat manajemen yang dapat digunakan untuk mendukung pencapaian tujuan organisasi dan menunjukkan keunggulan bersaing sehingga mampu menciptakan kinerja organisasi yang baik (Megantoro et al., 2014). Selain itu, hasil penelitian juga menunjukkan adanya pengaruh positif antara budaya organisasi terhadap kinerja organisasi, hasil penelitian ini mendukung penelitian (Zheng et al., 2010)

Selanjutnya hasil penelitian juga menunjukan bahwa pengaruh positif knowledge management terhadap kinerja organisasi hal ini mendukung pernyataannya dari Nonaka dan Takeuchi (1995) yang menyatakan bahwa bahwa Inovasi berkaitan dengan knowledge yang dapat digunakan untuk menciptakan produk atau proses dan layanan baru guna meningkatkan competitive advantage dan memenuhi kebutuhan pelanggan yang selalu berubah. Hasil penelitian juga menunjukkan bahwa budaya organisasi berpengaruh positif terhadap inovasi. Penelitian ini mendukung penelitiannya Martins dan Terblanche (2003) yang menyatakan bahwa untuk keberhasilan inovasi dan mengadopsi kemajuan teknologi, perusahaan harus mampu untk memenuhi psrsyaratan dalam hal prilaku internal dan hubungan eksternal pada saat bersamaan.

Penelitian ini tidak mendukung penelitian dari Al-Ansari et al. (2013) yang menunjukkan hubungan positif antara kinerja bisnis dan inovasi (Uzkurt et al., 2013; Zehir et al., 2011). Secara empiris penelitian meneliti hubungan knowledge management terhadap kinerja 
organisasi melalui inovasi. Penelitianini tidak mendukung penelitian López-Nicolás dan MeroñoCerdán (2011); Al-Hakim dan Hassan (2013) yang menyatakan bahwa knowledge management berpengaruh terhadap kinerja organisasi baik langsung maupun tidak langsung melalui inovasi. Secara empiris penelitian ini mendukung penelitian Noviyanti dan Mulyanto (2015); Yeşil et al. (2013) yang menyatakan knowledge management berpengaruh terhadap inovasi tetapi inovasi tidak mempunyai pengaruh terhadap kinerja organisasi.

Untuk mengetahui kenapa variabel inovasi tidak berpengaruh terhadap kinerja, peneliti melakukan wawancara dengan satu informan di organisasi penelitian pemerintah, wawancara tersebut dilakukan secara terarah dan mendalam. Adapun hasil dari wawancara tersebut adalah sebagai berikut:

"persepsi inovasi dengan aparatur sipil negara sebagai pelayan sudah berbeda domain pengelolaan, inovasi muncul karena adanya kebebasan berpikir dan bertindak akan tetapi karena dalam pemerintahan sudah ditetapkan indikator-indikator dan target yang hendak dicapai maka timbul adanya kesenjangan dalam inovasi“.

"karena ada anggapan bahwa otoritas wewenang sejalan dan searah dengan otoritas inovasi, maka inovasi seringkali bergantung pada individu yang memiliki otoritas wewenang yang memang berkeinginan untuk menghidupkan inovasi itu sendiri”.

Dalam Organisasi Penelitian Sektor Publik knowledge management system kurang optimal, hal tersebut ditegaskan dalam pernyataan informan yaitu "seharusnya pengetahuan yang dimiliki oleh seorang pengambil keputusan harus dijembatani dengan seringnya melakukan pertemuan-pertemuan (proses transfer knowledge) dengan para peneliti hal inilah yang kurang dilakukan di Organisasi Penelitian Pemerintah, alur transfer knowledge harusnya dari atas ke bawah, tetapi yang terjadi di lapangan adalah sebaliknya.

\section{Kesimpulan, Keterbatasan Penelitian Dan Saran}

\subsection{Kesimpulan}

Hasil penelitian menunjukkan bahwa (1) knowledge management berpengaruh terhadap inovasi, (2) knowledge management berpengaruh terhadap kinerja organisasi; (3) inovasi tidak berpengaruh terhadap Kinerja organisasi; (4) inovasi tidak memediasi hubungan knowledge management terhadap Kinerja organisasi.

\subsection{Keterbatasan Penelitian}

Terdapat beberapa keterbatasan penelitian ini yang dapat menjadi bahan pertimbangan bagi penelitian mendatang. Pertama, ukuran sampel yang kecil (small sample size) mungkin 
dapat mengurangi kekuatan pengujian statistikal selain itu, sampel penelitian ini berasal dari Organisasi Penelitian Pemerintah saja sehingga temuan penelitian ini tidak dapat digeneralisasi ke organisasi sector publik lainnya.

\subsection{Saran}

Penelitian mendatang dapat mempertimbangkan penggunaan ukuran sampel yang lebih besar dan dari Organisasi Penelitian Pemerintah dalam penelitian ini. Selain itu dapat juga dipertimbangkan penggunaan variabel lain, mengingat inovasi tidak berhasil memediasi knowledge management dan kinerja organisasi.

\section{Daftar Pustaka}

Agbim, K.C., G.O. Oriarewo, dan A.E. Omattah. 2013. An Exploratory Study of the Relationship between Innovation and Change Management. International Journal of Scientific and Research Publications, Vol. 3, Issue 6, June 2013.

Al-Ansari, Y., S. Pervan, dan J. Xu. 2013. Innovation and Business Performance of Smes: The Case of Dubai. Education, Business and Society: Contemporary Middle Eastern Issues, 6(3/4), 162-180.

Barney, J. 1991. Firm Resources and Sustained Competitive Advantage. Journal of management, 17(1), 99-120.

Carolina López-Nicolás, Á.L. Merõno-Cerdán, 2011. Strategic knowledge management, innovation and performance, International Journal of Information Management. 31: 502509

Damanpour, F. 1991. Organizational Innovation : A Meta-Analysis of Effects of Determinats and Moderators. Academy of Management Journal, Vol. 34, No. 3

Damanpour, F., dan M. Schneider. 2009. Characteristics of Innovation and Innovation Adoption in Public Organizations: Assessing the Role of Managers. Journal of public administration research and theory, 19(3), 495-522.

Fornell, Claes dan F.L. Bookstein (1982). Two structural Equation Models: LISREL and PLS Applied to Consumer Exit-Voice Theory. Journal of Marketing Research, XIX (November), 440-452

Geisser, Seymour 1975. The Predictive Sample Reuse Method with Applications. Journal of the American Statistical Association, 70 (June), 320-328

Ghozali, I. 2008. Structural Equation Modeling: Alternative Method with Partial Least Square (Pls). Semarang, Indonesia.

Honeycutt, J. 2000. Knowledge Management Strategies : Mapping Your Organization's Success in Today's Competitive Marketplace : Little, Brown \& Co. Inc

Kaplan, R. S., dan D. P. Norton. 1996. The Balanced Scorecard: Translating Strategy into Action: Harvard Business Press.

López-Nicolás, C., dan Á.L. Meroño-Cerdán. 2011. Strategic Knowledge management, Innovation and Performance. International journal of information management, 31(6), 502509. 
Martins, E., dan F. Terblanche. 2003. Building Organisational Culture That Stimulates Creativity and Innovation. European Journal of innovation management, 6(1), 64-74.

Megantoro, R. G., M. Miyasto, dan M. Rahardjo. 2014. Pengaruh Budaya Organisasi Terhadap Kinerja Organisasi Dengan Knowledge management Sebagai Variabel Mediating (Studi Empiris Pada Badan Pengawasan Keuangan Dan Pembangunan (Bpkp)). Diponegoro University.

Nielsen, P., P. Rasmussen, Y.-C. Hsiao, C.-J. Chen, dan S.-C. Chang. 2011. Knowledge management Capacity and Organizational Performance: The Social Interaction View. International Journal of Manpower, 32(5/6), 645-660.

Nonaka, I., dan H. Takeuchi. 1995. The Knowledge Creation Company: How Japanese Companies Create the Dynamics of Innovation. Oxford University Press. New York, USA, 304.

Nothnagel, K. 2008. Empirical Research within Resource-Based Theory: A Meta-Analysis of the Central Propositions: Springer Science \& Business Media.

Noviyanti, T., dan A. D. Mulyanto. 2015. Pengaruh Knowledge management Te Rhadap Inovasi, Implementasi Strategi Dan Kinerja Organisasi (Studi Pada Rs Lavalette Malang). Jurnal Ekonomi Bisnis, 20(1).

Salaman, Graeme dan J. Storey. 2002. Manager's Theories About the Process of Innovation. Journal of Management Studies, Vol. 39, Issue 2 March 2002.

Stone, M. 1974. Cross-Validatory Choice and Assessment of Statistical Predictions. Journal of the Royal Statistical Society, Series B (Methodological), 36 (2), 111-147

Uriarte A. Filemon, Introduction to Knowledge Management, ASEAN Foundation, 2008, Jakarta, Indonesia

Yeşil, S., dan A. Kaya. 2013. The Role of Organizational Culture on Innovation Capability: An Empirical Study. International Journal of Information Technology and Business Management, 6(1), 11-25.

Yeşil, S., A. Koska, dan T. Büyükbeşe. 2013. Knowledge Sharing Process, Innovation Capability and Innovation Performance: An Empirical Study. Procedia-Social and Behavioral Sciences, 75, 217-225.

Yousif Al-Hakim, L. A., dan S. Hassan. 2013. Knowledge management Strategies, Innovation, and Organisational Performance: An Empirical Study of the Iraqi Mts. Journal of Advances in Management Research, 10(1), 58-71.

Zehir, C., E. Altindag, dan A. Z. Acar. 2011. The Effects of Relationship Orientation through Innovation Orientation on Firm Performance: An Empirical Study on Turkish FamilyOwned Firms. Procedia-Social and Behavioral Sciences, 24, 896-908.

Zheng, W., B. Yang, dan G. N. McLean. 2010. Linking Organizational Culture, Structure, Strategy, and Organizational Effectiveness: Mediating Role of Knowledge management. Journal of Business Research, 63(7), 763-771. 